\title{
Main Chain Polysulfoxides as Active 'Stealth' Polymers with Additional Antioxidant and Anti-Inflammatory Behaviour
}

\author{
Farah El Mohtadi ${ }^{1}$, Richard d'Arcy ${ }^{2, *}$, Xiaoye Yang ${ }^{1,3}$, Zulfiye Yesim Turhan ${ }^{1}$, \\ Aws Alshamsan 4,5 and Nicola Tirelli $1,2, *$ (D) \\ 1 Division of Pharmacy and Optometry, School of Health Sciences, University of Manchester, Oxford Road, \\ Manchester M13 9PT, UK; Farah.elmohtadi@manchester.ac.uk (F.E.M.); yangxiaoyechn@outlook.com (X.Y.); \\ zulfiyeyesim.turhan@manchester.ac.uk (Z.Y.T.) \\ 2 Laboratory for Polymers and Biomaterials, Fondazione Istituto Italiano di Tecnologia, 16163 Genova, Italy \\ 3 Department of Pharmaceutics, College of Pharmacy, Shandong University, Jinan 250012, China \\ 4 Department of Pharmaceutics, College of Pharmacy, King Saud University, P.O. Box 2457, Riyadh 11451, \\ Saudi Arabia; aalshamsan@ksu.edu.sa \\ 5 Nanobiotechnology Unit, College of Pharmacy, King Saud University, P.O. Box 2457, \\ Riyadh 11451, Saudi Arabia \\ * Correspondence: Richard.Darcy@iit.it (R.d.); nicola.tirelli@iit.it (N.T.)
}

Received: 25 July 2019; Accepted: 14 September 2019; Published: 17 September 2019

\begin{abstract}
We present the evaluation of a sulfoxide-based polymer (poly(propylene sulfoxide), PPSO) as a potential 'stealth' macromolecule, and at the same time as a pharmacologically active (anti-inflammatory/anti-oxidant) material. The combination of these two concepts may at first seem peculiar since the gold standard polymer in biomaterials and drug delivery, poly(ethylene glycol) (PEG), is 'stealth' due to its chemical and biological inertness, which makes it hardly biologically active. Polysulfoxides, on the contrary, may couple a substantial inertness towards biomolecules under homeostatic conditions, with the possibility to scavenge reactive oxygen species (ROS) associated to inflammation. Polysulfoxides, therefore, are rather uniquely, 'active' 'stealth' polymers. Here, we describe the synthesis of PPSO through controlled oxidation of poly(propylene sulfide) (PPS), which on its turn was obtained via anionic ring-opening polymerization. In vitro, PPSO was characterized by a low toxicity (IC50 7 mg/mL at $24 \mathrm{~h}$ on human dermal fibroblasts) and a level of complement activation (in human plasma) and macrophage uptake slightly lower than PEG of a similar size. Importantly, and differently from PEG, on LPS-activated macrophages, PPSO showed a strong and dose-dependent ROS (hydrogen peroxide and hypochlorite)-scavenging activity, which resulted in a corresponding reduction of cytokine production.
\end{abstract}

Keywords: biocompatibility; bioinertness; oxidants; therapeutic polymers; responsive polymers; polysulfides

\section{Introduction}

For decades, poly(ethylene glycol) (PEG) has been considered the golden standard of synthetic macromolecules in biomedical applications, be it in the preparation of carriers for drug delivery (including several marketed or FDA-approved products $[1,2]$ ), proteins with reduced immunogenicity, [3,4], or matrices for tissue engineering/regenerative medicine [5]. PEG owes its widespread use to a combination of low toxicity [6] and 'stealth' character, which can be summarized as a prolonged circulation in body fluids and reduced clearance, as a result of negligible protein adsorption (opsonization) [4,7] and low activation of immune system components [8]. 
Indeed, an increase in hydrodynamic size upon PEGylation usually contributes to an overall longer circulation. PEG is not totally unique though: A number of polymers have been proposed as alternative stealth polymers, e.g., poly[N-(2-hydroxypropyl) methacrylamide](HPMA) [9-11], poly(vinylpyrrolidone)(PVP) [12,13], poly(2-methyl-2-oxazoline) (PMOX); [14,15], poly(N-acryloyl morpholine)(PAcM) [16,17], poly(N,N-dimethylacrylamide)(PDMA) [18], and polyglycerols [19]. The common feature in their macromolecular structure is the presence of very hydrophilic groups, which are poor nucleophiles and/or H-bond acceptors but not donors (Scheme 1, left).

Potentially 'stealth' building blocks Responsive, potentially therapeutic blocks
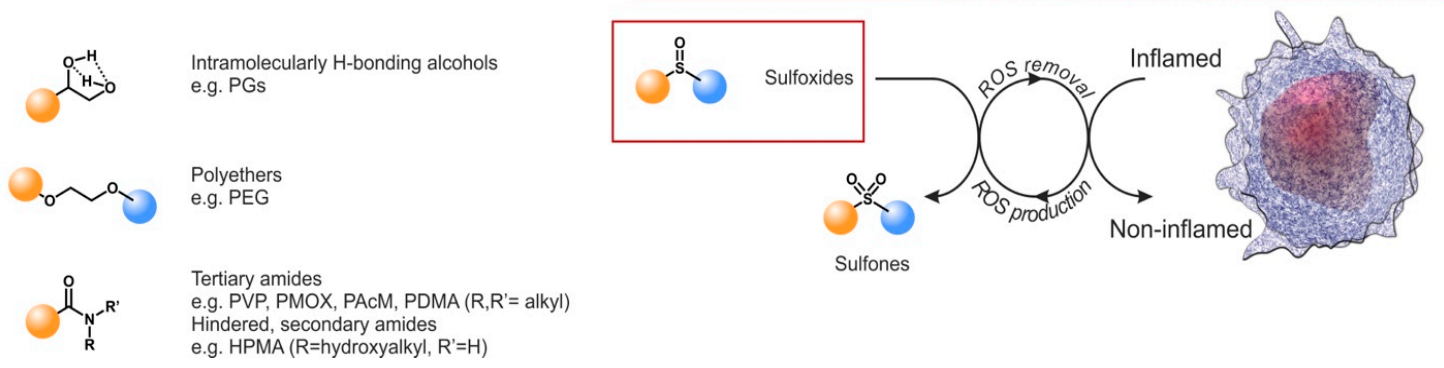

Scheme 1. Polysulfoxides can present features of 'stealth' materials (on the left hand of the scheme; common features: lack of nucleophilic or H-bond donating character, hydrophilicity) and of responsive structures (on the right hand of the scheme: OX-response through conversion of the sulfoxides to sulfones). Their potential for scavenging reactive oxygen species (ROS) can result in an overall anti-inflammatory activity.

'Stealth' materials have their drawbacks too, chiefly of an immunological nature, such as the accelerated blood clearance (ABC) $[20,21]$ after repeated injections of PEGylated materials. This phenomenon is predominantly ascribed to the production anti-PEG IgM antibodies [22,23], and may also link to the significant complement activation that PEG and PEG-containing structures can elicit in vivo [24,25]. IgMs bind to PEGylated carriers upon their second or later administration, and lead to their uptake by Kupffer cells in the liver [20,26], thereby competing and eventually overcoming the accumulation in tumours, the so-called enhanced permeation and retention (EPR) effect of PEGylated carriers [27]. Importantly, ABC is not observed only with PEG; for example, PMOX has recently been found to display an ABC effect macroscopically similar to that of PEG [28].

Another historical limit of 'stealth' drug delivery systems is that, as obvious as it may sound, biological inertness typically also means chemically and biologically inactive/unresponsive; for example, the presence of PEG - by virtue of its biological inertness-may reduce or slow down the accumulation of a carrier in a tissue or its endosomal escape (sometimes known as the "PEG dilemma") [7].

In this study, we focus on sulfoxides as building blocks of 'stealth' structures. Polymers based on sulfoxides are known for their very low cytotoxicity [29-31], and the idea to use them in a biological environment is not new. In the mid 1970s, Helmut Ringsdorf already saw the potential advantages of sulfoxide-containing polymers and studied side-chain sulfoxide polyacrylates (in particular poly(2-(methylsulfinyl)ethyl acrylate), PMSEA) as biocompatible and bioresorbable penetration enhancers [32]. PMSEA was recently proposed again by Matyjaszewski with more modern syntheses based on Atom Transfer Radical Polymerization (ATRP) [29], electrochemically mediated ATRP (eATRP) [33], and surface-initiated ATRP [34]. PMSEA has often been shown to behave similarly to poly(PEG acrylate), with the possible advantage of a lower steric hindrance; for example, their block copolymers with fluorine-containing monomers have a comparable MRI performance (slightly more intense signals for PMSEA) [35], and cationic hyperbranched constructs have similar transfection efficiency (but better polyplex formation for PMSEA) [36].

PMSEA is also occasionally referred to as poly(DMSO) [35] due its dimethyl sulfoxide (DMSO)-like side chain $\left(-\mathrm{CH}_{2} \mathrm{~S}(=\mathrm{O}) \mathrm{CH}_{3}\right)$. DMSO is indeed in itself one of the most benign/low toxicity organic solvents, being regularly used as a cryoprotective agent for cells and above all as a pharmaceutical 
excipient. Originally intended almost exclusively for the transdermal (topical) route, it is now increasingly employed in several parenteral and oral formulations [37]. Although toxic at high concentrations [38], at low concentrations, DMSO has a significant anti-inflammatory behaviour, e.g., reducing the lymphocyte activation [39], inhibiting M1 or M2 macrophage polarization, and ameliorating rheumatoid arthritis symptoms in mice [40]. These effects are likely due to DMSO's antioxidant (hydroxyl radical sequestering) activity of DMSO [41].

Our group has a long-running activity on oxidation-sensitive polymers [42]. We have specifically focused on polysulfides, employing them as reactive oxygen species (ROS)-scavengers, and as a result as anti-inflammatory agents $[43,44]$. In previous studies, we showed how the oxidation of thioethers can either stop at the level of sulfoxides or proceed to sulfones, depending on the conditions of oxidation and the nature of oxidant [30,45]. Here, we focus on the selective oxidation of poly(propylene sulfide) (PPS) to poly(propylene sulfoxide) (PPSO). Specifically, we present its evaluation as both a potential 'stealth' and an anti-inflammatory material, thereby condensing two apparently disjointed functions into the same macromolecular structure.

\section{Results and Discussion}

\subsection{Polymer Synthesis}

The anionic ring-opening polymerization (ROP) of propylene sulfide (PS) was initiated by a thiolate generated in situ through the deprotection of a thioacetate, in the presence of the reducing agent, tributylphosphine (Figure 1A); this combination minimizes the presence of disulfides, which act as chain transfer agents in episulfide polymerization [46], preventing them therefore from compromising the identity of the terminal groups of the final polymers, which would in turn increase their molecular weight dispersity. The polymerization was terminated by reacting the thiolate-terminated polymer with iodomethane, an end-capper previously employed by our group also for the determination of the instantaneous composition of copolysulfides and the determination of comonomeric reactivity ratios [47]. The initiator contained a second protected chemical function, a tetrahydropyranyl ether. After polymerization, the cleavage of this acetal with an acidic resin liberated a terminal primary alcohol, thereby yielding a heteroterminated polysulfide ( $\alpha$-hydroxy- $\omega$-methyl-PPS, hereafter referred to as mPPSO-OH for homogeneity of nomenclature with mPEG-OH). The two different termini allowed for the determination of the polymer size $\left(\overline{M_{n}}\right)$ via ${ }^{1} \mathrm{H} N \mathrm{NR}$, which rather closely confirmed the data from GPC analysis (Table 1), as well as the efficiency of end-capping. Please note that termination and initiation groups were chosen to keep the polymers as similar as possible to the $5 \mathrm{kDa} \mathrm{mPEG}-\mathrm{OH}$.

The oxidation of PPS was performed using near stoichiometric amounts of $\mathrm{H}_{2} \mathrm{O}_{2}$ combined with catalytic amounts of DPDS; the latter has been recently introduced as a catalyst for the selective oxidation of thioethers to sulfoxides in organic solvents using stoichiometric amounts of a urea $/ \mathrm{H}_{2} \mathrm{O}_{2}$ complex [48]. In comparison to this literature, we found that the oxidation proceeded equally well adding aqueous $(30 \%) \mathrm{H}_{2} \mathrm{O}_{2}$ to a DMF solution of PPS in the absence of urea. We also saw that the process is selective towards sulfoxides only on the basis of the amount of oxidant added: With 1.1 equiv.s of $\mathrm{H}_{2} \mathrm{O}_{2}$, a well-characterized PPSO is obtained (Figure $1 \mathrm{~B}, \mathrm{C}$ ), essentially with the chain length as the parent PPS (Figure 1D). However, with 2.2 equiv.s of $\mathrm{H}_{2} \mathrm{O}_{2}$, a polymer was obtained $\left(\mathrm{PPSO}_{2}\right)$ where sulfoxides were clearly further oxidized to sulfones: The $\mathrm{PPSO}_{2} \mathrm{IR}$ spectrum showed the well-recognizable asymmetric $\left(v_{\mathrm{as}} \mathrm{SO}_{2}\right)$ and symmetric $\left(v_{\mathrm{S}} \mathrm{SO}_{2}\right)$ stretching bands of sulfones at 1296 and $1121 \mathrm{~cm}^{-1}$ replacing that of sulfoxides $\left(\vee \mathrm{S}=\mathrm{O}\right.$ ) at $\sim 1017 \mathrm{~cm}^{-1}$ (Figure $1 \mathrm{~B}$ ), and also ${ }^{1} \mathrm{H}$ NMR showed a clear downfield effect of the broad bands of a still polymeric structure (Figure 1C). It is, however, possible that $\mathrm{PPSO}_{2}$ has undergone significant chain cleavage: It's very limited solubility—only in DMSO or basified water-which also prevents the usual GPC analysis—and an IR band at $844 \mathrm{~cm}^{-1}$ possibly ascribed to $\checkmark \mathrm{S}-\mathrm{O}$ vibration may indicate the presence of sulfenic acids. The latter are necessarily terminal groups, whose formation is consistent with the easy fragmentation (low ceiling temperature) 
of macromolecules based on aliphatic sulfones [30]. Due to the more difficult characterization of $\mathrm{PPSO}_{2}$, and to its likely low stability, in the rest of the study, we only focused on PPSO.

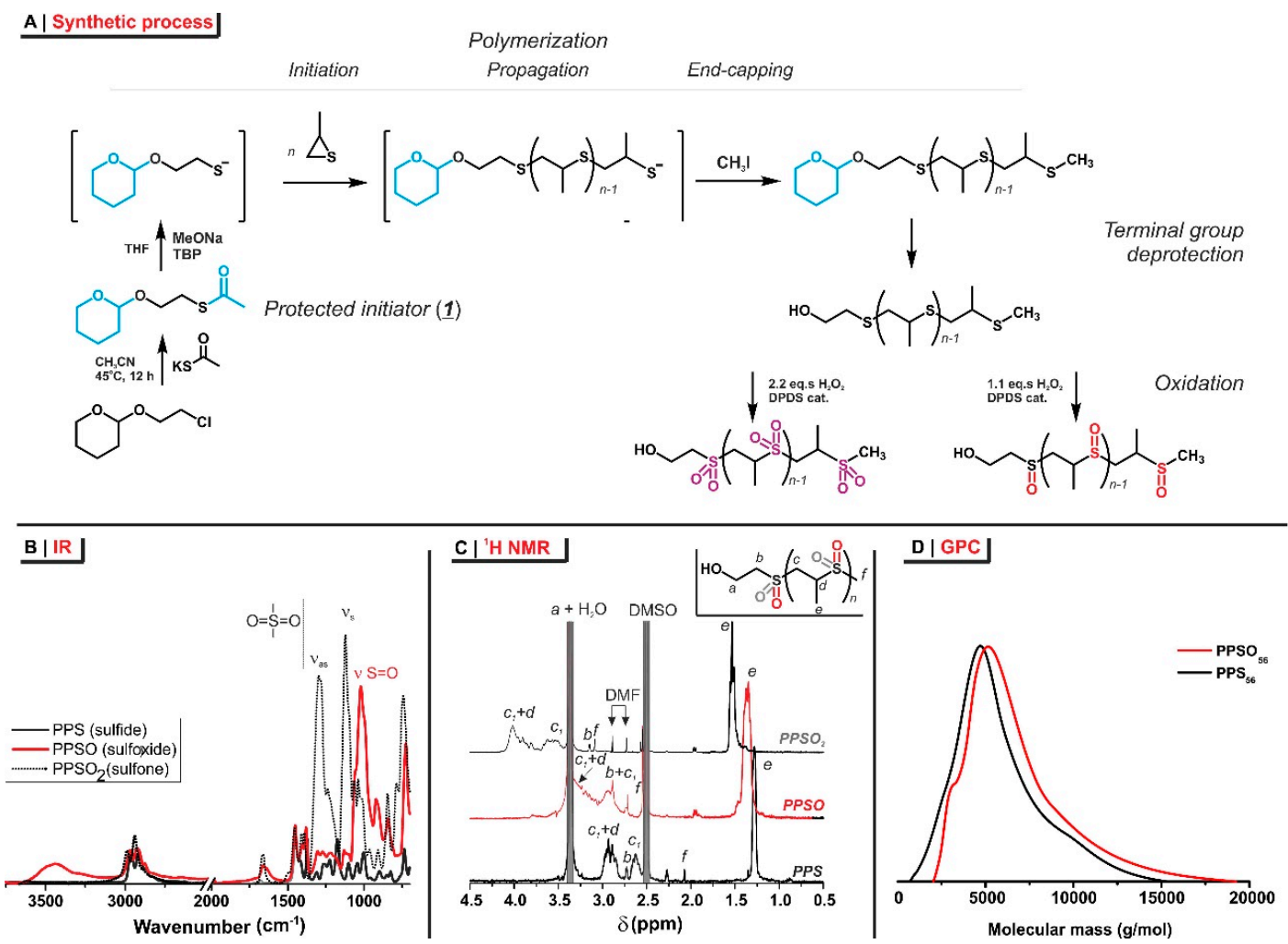

Figure 1. (A) Synthetic process for the preparation of $\alpha$-hydroxy- $\omega$-methyl-poly(propylene sulfoxide), and of the corresponding sulfone-containing (further oxidized) polymer. Diphenyl diselenide (DPDS) was used as a catalyst (at $\sim 0.025$ equiv.s per thioether) in the final oxidation reactions. In blue, the protected groups present in compound 1 , which provides a thiolate to initiate the polymerization and a primary alcohol in the final polymer. (B) FT-IR spectra of PPS $_{56} 24 \mathrm{~h}$ after oxidation with 1.1 equiv.s of $\mathrm{H}_{2} \mathrm{O}_{2}$ (PPSO) or 2.2 equiv.s $\left(\mathrm{PPSO}_{2}\right.$ ), with the indication of bands diagnostic for the oxidized groups. The spectra are normalized to the maximum of their $v_{\text {as }} \mathrm{CH}_{3}$ band at $\sim 2960 \mathrm{~cm}^{-1}$. Please note that the band above $3000 \mathrm{~cm}^{-1}$ in PPSO's spectrum shows the presence of water due to the hygroscopic nature of the polymer. (C) ${ }^{1} \mathrm{H}$ NMR spectra (in $d 6$-DMSO) of PPS, $\mathrm{PPSO}$, and $\mathrm{PPSO}_{2}$. Letters correspond to the assignments labelled on the structure in the inset. (D) Triple detection GPC traces of PPS and PPSO (in DMF with $0.1 \% \mathrm{LiBr}$ ).

Table 1. Molecular weight data of mPPS-OH and mPPSO-OH.

\begin{tabular}{|c|c|c|c|c|c|}
\hline & \multicolumn{3}{|c|}{$\overline{M_{n}}(\mathrm{~g} / \mathrm{mol}) / \overline{D P_{n}}$} & \multirow{2}{*}{$\bigoplus^{b}$} & \multirow{2}{*}{$\begin{array}{l}\text { End-Capping } \\
\text { Yield (mol \%) }^{\mathrm{c}}\end{array}$} \\
\hline & Theor. & ${ }^{1} \mathrm{H}_{\mathrm{NMR}}{ }^{\mathrm{a}}$ & GPC $^{b}$ & & \\
\hline $\mathrm{mPPS}_{56}-\mathrm{OH}$ & $4315 / 56$ & $4390 / 57$ & $3850 / \approx 49$ & 1.26 & 98 \\
\hline $\mathrm{mPPSO}_{56}-\mathrm{OH}$ & $5211 / 56$ & $5300 / 57$ & $4400 / \approx 47$ & 1.21 & not applicable \\
\hline
\end{tabular}

a $\overline{D_{n}}$ obtained from the comparison of the resonance of primary alcohol's $\mathrm{CH}_{2}$ group at $\sim 3.75 \mathrm{ppm}$ with the main chain methyl peak of PPS at $\sim 1.33$ to $1.45 \mathrm{ppm}$ (resonances $a$ and $e$ in the $\mathrm{CDCl}_{3}$ spectrum of deprotected $\mathrm{mPPS}-\mathrm{OH}$; see Supplementary Materials, Figure 1SI). $\overline{M_{n}}$ calculated from $\overline{D P_{n}}$ b From triple detection GPC in DMF containing $0.1 \%$ LiBr. ${ }^{\mathrm{c}}$ From the comparison of the ${ }^{1} \mathrm{H}$ NMR resonances of the two terminal groups (resonances $a$ and $f$ in the $\mathrm{CDCl}_{3}$ spectrum of deprotected PPS; Supplementary Materials, Figure 1SI).

\subsection{Potentially "Stealth" Character and Anti-Inflammatory Properties}

Firstly, the PPSO backbone appeared to be characterized by a low toxicity. mPPSO-OH showed a very low capacity to reduce the viability of HDFn (IC50 $\sim 7 \mathrm{mg} / \mathrm{mL}$ at $24 \mathrm{~h}$ (Figure $2 \mathrm{~A}$ ) and $\sim 3 \mathrm{mg} / \mathrm{mL}$ 
at $48 \mathrm{~h}$ (Figure 3A) using the MTS assay). mPPSO-OH does appear to be more toxic than mPEG-OH, however, only at the very high end of the concentration range usable for in vivo applications that most commonly is well below $1 \mathrm{mg} / \mathrm{mL}$ (consider that either protein or polymer conjugates are injected to doses ranging between from $\mu \mathrm{g} / \mathrm{kg}$ to a few $\mathrm{mg} / \mathrm{kg}$ [49,50]). Indeed, at (and up to) $1 \mathrm{mg} / \mathrm{mL}$, the two polymers are virtually indistinguishable (Figure 2C). The effect of PPSO on viability is likely ascribed to its capacity to scavenge ROS, like its parent polymer PPS [44]; small amounts of ROS are essential to many cellular processes [51] and high doses of PPSO may indeed scavenge them to less-than-homeostatic levels.
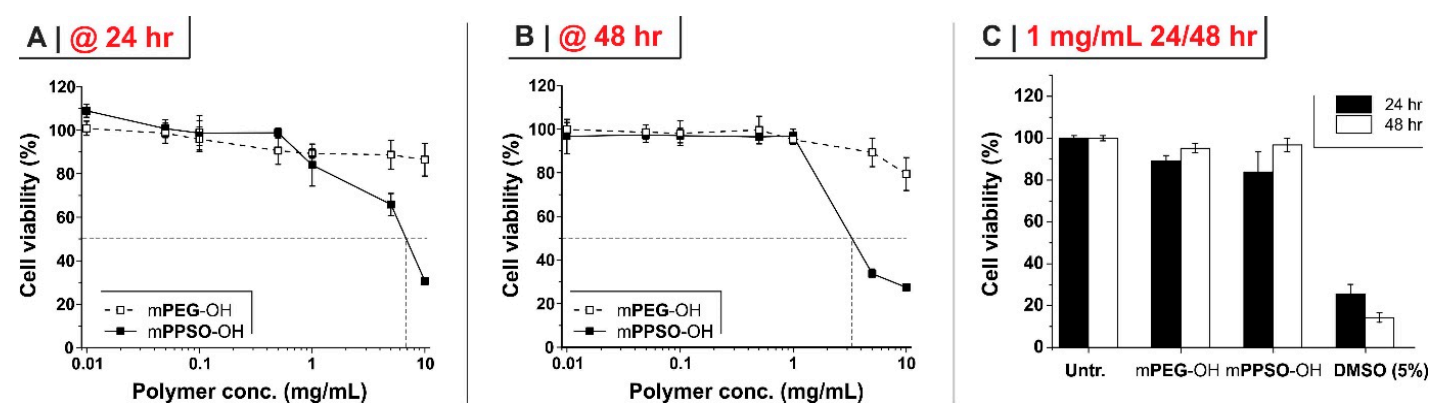

Figure 2. (A) The mitochondrial reductase activity (MTS assay) was used as a measure of the viability of HDFn, when cultured for $24 \mathrm{~h}$ in the presence of $\mathrm{mPPSO}-\mathrm{OH}$ or the analogous mPEG-OH. Horizontal and vertical dashed lines allow the individuation of the IC50 as their intersection point $(n=3)$. (B) As in A, for $48 \mathrm{~h}$. (C) Visual comparison of HDFn viability after exposure to $1 \mathrm{mg} / \mathrm{mL} \mathrm{mPPSO}-\mathrm{OH}$ and mPEG-OH for 24 (black bars) and $48 \mathrm{~h}$ (white bars), also reporting 5\% DMSO as a positive control.

In a preliminary assessment of possible foreign-body responses, $\mathrm{mPPSO}-\mathrm{OH}$ behaved similarly to 'stealth' polymers, such as PEG and PMOX. The complement pathway, being part of the innate immune system, is a critical defence mechanism whose activation allows recognition and elimination of potentially harmful foreign pathogens. Complement activation is therefore a major factor in the assessment of the biocompatibility of a polymer. For example, materials, such as regenerated cellulose [52], poly(hydroxyethyl methacrylate) (pHEMA) [53], and plasticized PVC [54], and most commonly polymers that are either strongly hydrophobic or displaying nucleophilic alcohols are potent complement activators. Very hydrophilic, poorly nucleophilic, and $\mathrm{H}$-bond accepting polymers (='stealth' polymers) have a better performance: Dextran [55] or poly(N-vinylpyrrolidone) (PVP) [56] are moderate to weak activators, and polyoxazolines [57], PEG [58] (but not necessarily its block copolymers, such as Pluronics [25]), and phosphoryl choline-based macromolecules [59] are lowto non-activating.

Here, we compared the capacity of mPPSO-OH to produce $\mathrm{C} 3 \mathrm{a}$ and $\mathrm{C} 5 \mathrm{a}$ anaphylatoxins (the small, soluble fragments of complement $\mathrm{C} 3$ and $\mathrm{C} 5$ proteins liberated upon cleavage by their respective $\mathrm{C} 3$ or $\mathrm{C} 5$ convertase) from human plasma with those of mPEG-OH and mono-hydroxy poly(2-methyl oxazoline) (PMOX-OH), using zymosan as a positive control (Figure 3A,B). Please note that the three synthetic polymers are all of similar size (around $5 \mathrm{kDa}$ ) and all feature one terminal $\mathrm{OH}$ group. At any of the three concentrations tested, complement activation followed the trend: Zymosan >> mPEG-OH $\geq$ PMOX-OH $\geq$ mPPSO-OH. In a direct comparison to mPEG-OH, at a concentration of $0.8 \mathrm{mg} / \mathrm{mL}$ mPPSO-OH produced 30\% less C3a and 34\% less C5a than mPEG-OH. As a caveat, an in vitro low complement activation does not imply the absence of complement-related issues in vivo; for example, complement plays a major role in the initiation of $A B C$ observed with theoretically low activators, such as PEGylated, and probably also with PMOXylated nano-carriers. 

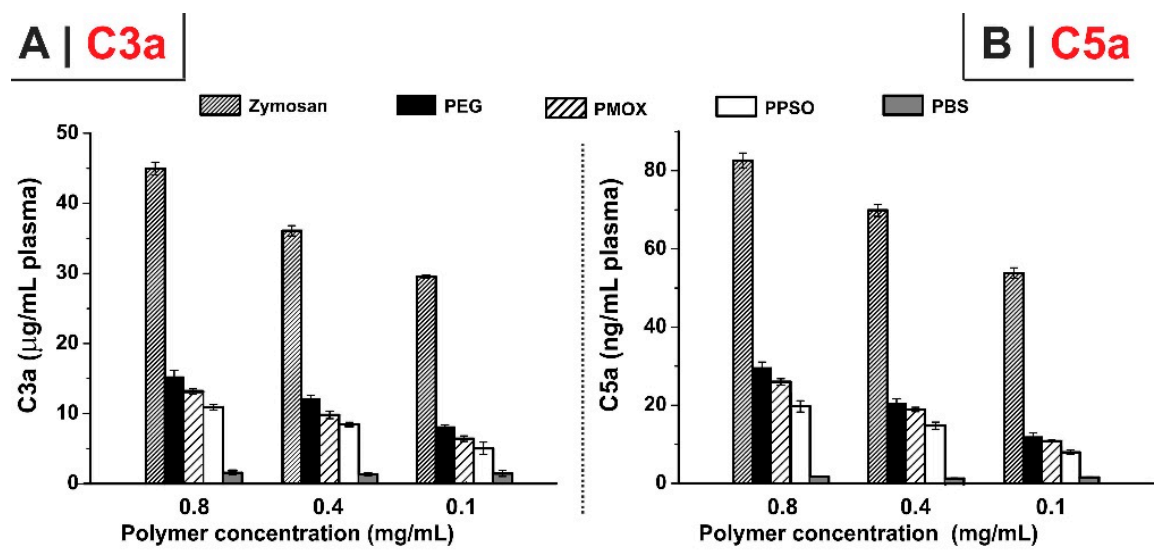

\section{C | Macrophage uptake}
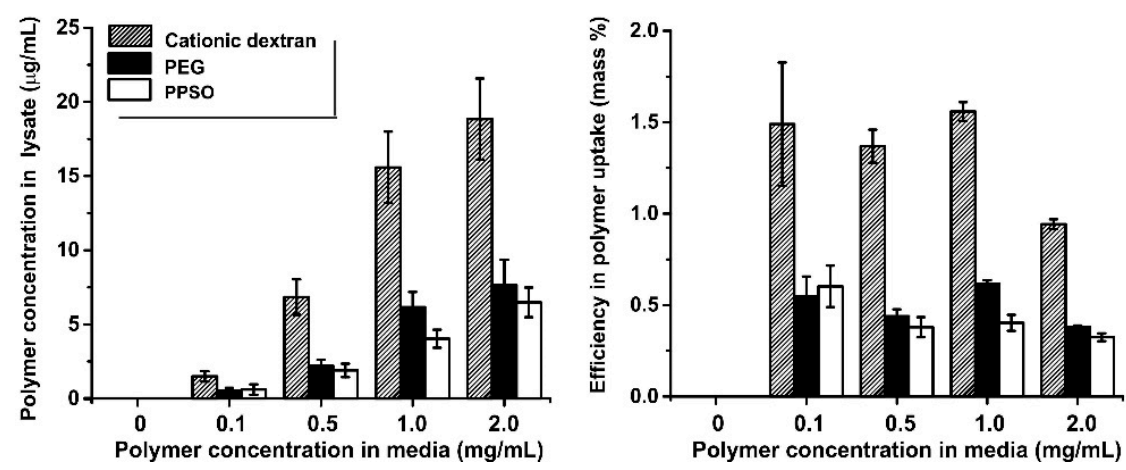

Figure 3. (A) ELISA-based assessment of the production of $\mathrm{C} 3 \mathrm{a}$ complement fragment upon incubation of human plasma with zymosan (positive control), PEG, PMOX, PPSO, and PBS (negative control) at three different concentrations $(n=3)$. (B) As in A for the complement fragment C5a (right), in human plasma. (C) Uptake of fluorescein-labelled PEG and PPSO (the terminal OH groups were converted to amines and reacted with FITC) and FITC-labelled cationic dextran after $24 \mathrm{~h}$ incubation in RAW264.7 macrophages activated with $500 \mathrm{ng} / \mathrm{mL}$ LPS. The left graph reports the concentration of the polymers in $100 \mu \mathrm{L}$ of cell lysates, the right graph normalizes the amount of polymer found in lysates (concentration*volume) against the total amount of polymer cells they were incubated with; this provides a measure of the efficiency of uptake $(n=3)$. The polymer uptake in untreated RAW264.7 macrophages is provided in Supplementary Materials, Figure 2SI.

Finally, the low uptake of PPSO by activated macrophages also suggests a 'stealth' behaviour. Murine RAW264.7 macrophages were activated with LPS and exposed for $24 \mathrm{~h}$ to various concentrations of FITC-labelled PPSO, PEG, or cationic dextran, which was used as a positive control; cell lysates were then used to quantify the polymer uptake, including in it both the material internalized and that bound on cell surfaces.

At any of the four concentrations tested, the 24-h uptake varied in the order, cationic dextran >> PEG $\geq$ PPSO (Figure 3C, left); this trend becomes even more apparent when looking at the uptake efficiency ( $\%$ of polymer taken by cells; Figure 3C, right). In short, PPSO appears to resist both binding and internalization in activated macrophages similarly, if not marginally better than PEG. This general behaviour is likely ascribed to the same substantial lack of interactions between PEG or PPSO and biomolecules, with internalization probably only occurring through non-receptor-mediated mechanisms, e.g., macropinocytosis. Although the PPSO/PEG difference is not statistically significant in all cases, the uptake of the PPSO is typically lower; this might be caused by partial de-activation of the macrophages as a result of ROS scavenging, which we previously invoked to explain the slightly higher toxicity of PPSO. To that end, it is therefore necessary to demonstrate that PPSO is indeed both ROS scavenging and anti-inflammatory. 
To do that, we measured the concentration of two of the most important biological $\mathrm{ROS}\left(\mathrm{H}_{2} \mathrm{O}_{2}\right.$ and $\mathrm{ClO}^{-}$) in cell lysates, thereby accounting for both intra- and extracellular ROS. PPSO reduced the levels of both ROS in a dose-dependent fashion, whereas at no concentration did PEG appear to have an influence on their levels (Figure 4A). This differential PEG/PPSO behaviour was also recorded on the extracellular levels of TNF- $\alpha$, whose dose-dependent reduction with PPSO concentration is ascribed to ROS scavenging (Figure 4B, as we have seen, e.g., in vitro and in vivo with PPS (polysulfide) nanoparticles) [44].
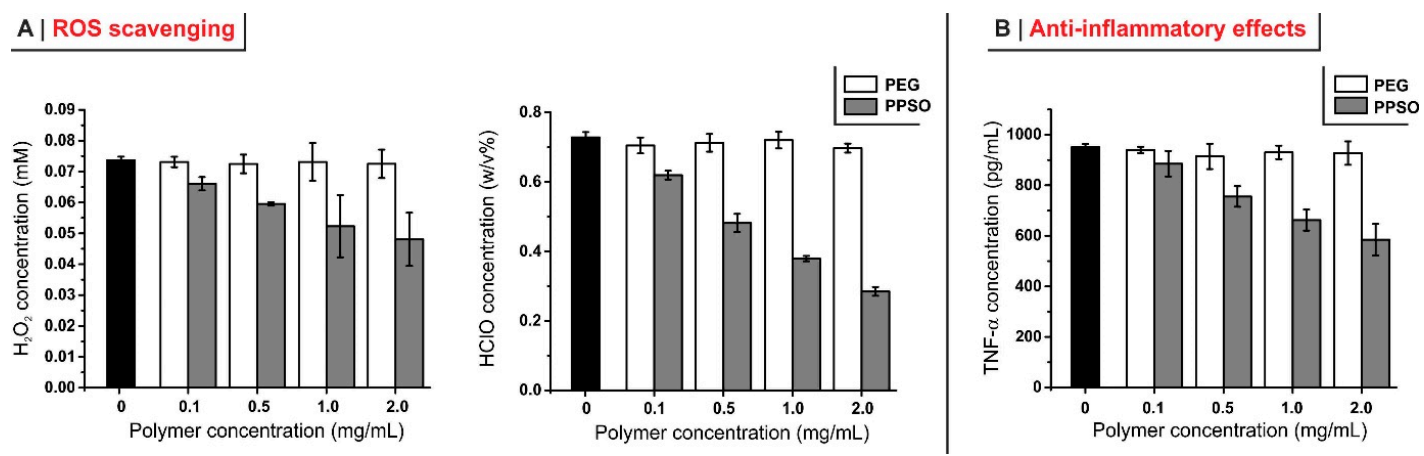

Figure 4. (A) Concentration of $\mathrm{H}_{2} \mathrm{O}_{2}$ (left) and hypochlorite (right) in cell lysates after $24 \mathrm{~h}$ exposure of LPS-activated macrophages to mPEG-OH and mPPSO-OH. Please note that although hypochlorite is more commonly associated to the neutrophil respiratory burst, it is also routinely produced by LPS stimulated macrophages [60]. (B) The anti-inflammatory activity of PPSO was evaluated by measuring the TNF- $\alpha$ levels in the supernatant of RAW264.7 macrophages stimulated with LPS and exposed for $24 \mathrm{~h}$ to $\mathrm{mPPSO}-\mathrm{OH}$ or mPEG-OH.

\section{Materials and Methods}

\subsection{Materials, (Bio)Chemicals, and Cells}

All chemicals were used as received from suppliers unless otherwise stated. S-methyl thioacetate, sodium methoxide (MeONa, 0.5 M in methanol), tributyl phosphine,1,8-diazabicyclo[5.4.0]undec-7-ene (DBU), sodium sulfate anhydrous $\left(\mathrm{Na}_{2} \mathrm{SO}_{4}\right)$, dichloromethane, tetrahydrofuran (THF), $\mathrm{N}, \mathrm{N}$-dimethyl formamide (DMF), methanol, and hydrochloric acid $1 \mathrm{M}(\mathrm{HCl})$ were purchased from Thermo Fisher Scientific (Loughborough, UK). HPLC grade DMF was purchased from Alfa Aesar/Thermo Frsher. Trifluoroacetic acid (TFA), poly(ethylene glycol) monomethyl ether (mPEG-OH) (5 kDa), and mono hydroxy-terminated poly(2-methyl-2-oxazoline) (PMOX-OH) were purchased from Sigma-Aldrich (Gillingham, UK). Phosphate buffered saline (PBS) Dulbecco A tablets were purchased from Oxoid (Basingstoke, UK). Further, 30\%wt. $\mathrm{H}_{2} \mathrm{O}_{2}$ was purchased from VWR (Leicester, UK) and titrated to determine its actual concentration prior to use. C3a, C5a Platinum ELISA kits were purchased from eBioscience (San Diego, CA, USA).

Human dermal fibroblasts (neonatal) (HDFn) and lipopolysaccharides (LPS) from Escherichia coli 026:B6 were purchased from Thermo Fisher Scientific; RAW264.7 Macrophages were purchased from ATCC. Citrated human plasma, fluorescein isothiocyanate (FITC), and FITC-labelled cationic dextran (nominal molecular weight of $4 \mathrm{kDa}$ ) were purchased from Sigma Aldrich. Dulbecco's modified Eagle's medium (DMEM), fetal bovine serum (FBS), L-glutamine $200 \mathrm{mM}(\times 100)$, and penicillin-streptomycin were purchased from Invitrogen (Paisley, UK). The MTS proliferation assay (CellTiter $96{ }^{\circledR}$ Aqueous One Solution Cell Proliferation Assay) was purchased from Promega (Madison, WI, USA). The ELISA kit for TNF $\alpha$ was purchased from Cohesion Biosciences (London, UK). The Hypochlorite Assay Kit (colorimetric, absorbance at $555 \mathrm{~nm}$ ) and Hydrogen Peroxide Assay Kit (colorimetric/fluorometric; exc. $535 \mathrm{~nm}$, em. $587 \mathrm{~nm}$ ) were purchased from MitoSciences, Abcam ${ }^{\circledR}$ (Cambridge, UK). 


\subsection{Physico-Chemical Characterization}

${ }^{1} \mathrm{H}$ NMR spectra were recorded on $1.5 \% \mathrm{wt}$. solutions in deuterated chloroform and dimethyl sulfoxide (d6-DMSO) using a Bruker Avance 300 or $400 \mathrm{MHz}$ Bruker spectrometer.

FT-IR spectra were recorded in ATR mode (Golden Gate) on a Tensor 27 Bruker spectrometer (Bruker UK Limited, UK) equipped with a 3000 Series TM High Stability Temperature Controller (Specac, UK).

Gel permeation chromatography (GPC) analysis was performed using triple detection conditions with a Malvern OmniSec System (Malvern, UK) comprising of a D6000M and D3000 column in sequence and operating online at $50{ }^{\circ} \mathrm{C}$ with HPLC grade DMF containing $0.1 \% \mathrm{LiBr}$ as the mobile phase at a flow rate of $1.0 \mathrm{~mL} / \mathrm{min}$. Calibration was performed using a poly(methyl methacrylate) standard of a known molecular weight, intrinsic viscosity, and dn/dc.

UV-Vis and fluorescence readings were obtained through a BioTek Synergy 2 multimode microplate reader (BioTek, UK) at a temperature of $37^{\circ} \mathrm{C}$.

\subsection{Preparative Operations}

\subsubsection{S-(2-((Tetrahydro-2H-pyran-2-yl)oxy)ethyl) ethanethioate (1)}

In total, $6.0 \mathrm{~g}$ (36.4 mmol) of 2-(2-chloroethoxy)tetrahydro-2H-pyran and $6.24 \mathrm{~g}$ (54.67 mmol, 1.5 equiv.s) of potassium thioacetate were added under argon to $100 \mathrm{~mL}$ of acetonitrile in a three-necked rounded-bottom flask. The mixture was added to a heating bath at $45^{\circ} \mathrm{C}$ and allowed to stir overnight $(\sim 12 \mathrm{~h})$. Volatiles were removed by rotary evaporation and the viscous oil was dissolved into $80 \mathrm{~mL}$ of diethyl ether and extracted against $20 \mathrm{~mL}$ of a $5 \%$ sodium bicarbonate solution $(\times 3)$ then brine $(2 \times)$. The organic phase was separated, dried over $\mathrm{Na}_{2} \mathrm{SO}_{4}$, filtered, and concentrated in vacuo. The resulting oil was purified by column chromatography using silica as the stationary phase and 9:1 hexane:ethyl acetate as the mobile phase to yield $6.0 \mathrm{~g}$ of faintly yellow oil ( $81 \%$ yield).

${ }^{1} \mathrm{H} \mathrm{NMR}\left(\mathrm{CDCl}_{3}\right): \delta=1.46-1.91\left(\mathrm{~m}, 6 \mathrm{H},-\mathrm{OCH}-\left[\left(\mathrm{CH}_{2}\right)_{3}-\mathrm{CH}_{2}-\mathrm{O}-\right]\right), 2.35\left(\mathrm{~s}, 3 \mathrm{H},-\mathrm{S}-\mathrm{C}(=\mathrm{O})-\mathrm{CH}_{3}\right)$, 3.09-3.18 (t, 2H, -O-CH $\left.{ }_{2}-\mathrm{CH}_{2}-\mathrm{S}-\right)$, 3.46-3.61 (m, 2H, -OCH-[( $\left.\left.\left(\mathrm{CH}_{2}\right)_{3}-\mathrm{CH}_{2}-\mathrm{O}-\right]\right), 3.78-3.92(\mathrm{~m}, 2 \mathrm{H}$, $\left.-\mathrm{O}-\mathrm{CH}_{2}-\mathrm{CH}_{2}-\mathrm{S}-\right)$, $4.60-4.66 \mathrm{ppm}\left(\mathrm{t}, 1 \mathrm{H},-\mathrm{OCH}-\left[\left(\mathrm{CH}_{2}\right)_{3}-\mathrm{CH}_{2}-\mathrm{O}-\right]\right)$.

\subsubsection{Monohydroxy-Terminated Poly(Propylene Sulfide) (PPS) $)_{56}$}

In total, $246 \mathrm{mg}$ (1.20 mmol) of S-(2-((tetrahydro-2H-pyran-2-yl)oxy)ethyl) ethanethioate, $10.89 \mathrm{~mL}$ ( $3.61 \mathrm{mmol}, 3$ equiv.s) of tributylphosphine and then $2.53 \mathrm{~mL}$ (1.26 mmol, 1.05 equiv.s) of a $0.5 \mathrm{M}$ sodium methoxide in methanol solution were added under an argon atmosphere to $12 \mathrm{~mL}$ of degassed THF (bubbled with argon for $45 \mathrm{~min})$. After $10 \mathrm{~min}, 5.0 \mathrm{~g}$ (67.43 mmol, 56 equiv.s) of PS were added and allowed to react for a further $75 \mathrm{~min}$. Next, $342 \mathrm{mg}$ ( $2.41 \mathrm{mmol}, 2$ equiv.s) of iodomethane were added and allowed to react for $60 \mathrm{~min}$; excess iodomethane was quenched by $1.2 \mathrm{~mL}(2.41 \mathrm{mmol}$, 2 equiv.s) of a $2 \mathrm{M}$ dimethylamine in THF solution. Volatiles were removed in a Genevac EZ2 Elite centrifugal evaporator and the resulting oil was dissolved in $40 \mathrm{~mL}$ of dichloromethane and extract 5 times against $10 \mathrm{~mL}$ of brine. The organic phase was separated, dried over $\mathrm{Na}_{2} \mathrm{SO}_{4}$, filtered and concentrated in vacuo. The concentrated oil was then precipitated into $8 \mathrm{~mL}$ of $\mathrm{MeOH}$, centrifuged, and the $\mathrm{MeOH}$ phase decanted. The pellet was washed with $5 \mathrm{~mL}$ of $\mathrm{MeOH}$ a further 3 times and dried in vacuo to yield colourless viscous oil. Please note that the initiator was probably partially deprotected, most likely as a result of $\mathrm{HI}$ formed during iodomethane quenching.

Deprotection. In total, $2.0 \mathrm{~g}$ of PPS $_{56}(0.47 \mathrm{mmol})$ were dissolved into $5 \mathrm{~mL}$ of a 1:1 methanol/THF mixture, to which 3 drops of water were added before being transferred to a reaction flask containing $1.4 \mathrm{~g}$ of acidic ion exchange resin Dowex 50W X8 (70 wt. \% of PPS 56 weight), which was activated with $1.0 \mathrm{M} \mathrm{HCl}$ prior to the reaction. The mixture was then heated to $50^{\circ} \mathrm{C}$ and allowed to react for $24 \mathrm{~h}$ (no stirring). Resin was filtered out and the volatiles were removed under reduced pressure to produce colourless viscous oil. 
${ }^{1} \mathrm{H}$ NMR $\left(\mathrm{CDCl}_{3}\right): \delta=1.30-1.45$ (d, $\mathrm{CH}_{3}$ in PPS chain), 2.13 (s, 3H, $-\mathrm{CH}\left(\mathrm{CH}_{3}\right)-\mathrm{S}_{-}-\mathrm{CH}_{3}$, terminal methyl), 2.56-2.71 (m, PPS chain: 1 diastereotopic $\mathrm{CH}_{2}$ ), 2.74-2.80 ( $\left.\mathrm{t}, 2 \mathrm{H}, \mathrm{HO}-\mathrm{CH}_{2}-\mathrm{CH}_{2}-\mathrm{S}-\right)$, 2.81-3.05 (m, $\mathrm{CH}$ and 1 diastereotopic $\mathrm{H}$ of $\mathrm{CH}_{2}$ in PPS chain), 3.72-3.79 ppm (t, $\left.2 \mathrm{H}, \mathrm{HO}-\mathrm{CH}_{2}-\mathrm{CH}_{2}-\mathrm{S}-\right)$.

ATR FT-IR (thin film): $2959\left(v_{\mathrm{s}} \mathrm{CH}_{3}\right), 2918\left(v_{\mathrm{as}} \mathrm{CH}_{2}\right), 2865\left(v_{\mathrm{as}} \mathrm{CH}_{3}\right.$ and $\left.v_{\mathrm{s}} \mathrm{CH}_{2}\right), 1450\left(\delta_{\mathrm{s}} \mathrm{CH}_{2}\right)$, $1371\left(\delta_{\mathrm{s}} \mathrm{CH}_{3}\right), 1171\left(\mathrm{CH}_{2} \mathrm{wag}\right), 734\left(\rho \mathrm{CH}_{2}\right)$, and $689 \mathrm{~cm}^{-1}(\vee \mathrm{C}-\mathrm{S})$.

\subsubsection{Poly(Propylene Sulfoxide) mPPSO-OH and Poly(Propylene Sulfone) $\mathrm{mPPSO}_{2}-\mathrm{OH}$}

In total, $1.75 \mathrm{~g}$ of PPS ( $23 \mathrm{mmol}$ of thioethers) and $180 \mathrm{mg}$ of diphenyl diselenide (DPDS) ( $0.58 \mathrm{mmol}, \sim 0.025$ equiv.s per thioethers) were dissolved in $25 \mathrm{~mL}$ of DMF. Either $2.6 \mathrm{~mL}$ ( $25.45 \mathrm{mmol}$, 1.1 equiv.s per thioether) or $5.2 \mathrm{~mL}$ ( $50.90 \mathrm{mmol}, 2.2$ equiv.s per thioether) of a $30 \%(\mathrm{w} / \mathrm{w}) \mathrm{H}_{2} \mathrm{O}_{2}$ aqueous solution were then added and allowed to react for 24 hours for the PPSO or $\mathrm{PPSO}_{2}$ syntheses respectively. Note, upon addition of the aqueous $\mathrm{H}_{2} \mathrm{O}_{2}$, some precipitation/cloudiness of PPS occurred, and a small amount of acetone was added to give a clear solution. The solution was evaporated using a Genevac EZ2 Elite centrifugal evaporator and the resulting oil was dissolved into a small amount of dichloromethane and precipitated into diethyl ether (5 times). The resulting pellet was dried in a vacuum oven at $40{ }^{\circ} \mathrm{C}$ for $24 \mathrm{~h}$ to give a white solid.

PPSO. ${ }^{1} \mathrm{H}$ NMR (CDCl3): $\delta=1.29-1.66\left(\mathrm{CH}_{3}\right.$ in PPSO chain), $3.09\left(\mathrm{~s}, 3 \mathrm{H},-\mathrm{CH}\left(\mathrm{CH}_{3}\right)-\mathrm{S}(=\mathrm{O})_{2}-\mathrm{CH}_{3}\right.$, terminal methyl), 2.61-3.01 ( $\mathrm{HO}-\mathrm{CH}_{2}-\mathrm{CH}_{2}-\mathrm{S}(=\mathrm{O})$ - and $\mathrm{PPSO}$ chain: 1 diastereotopic $\mathrm{CH}_{2}$ ), 3.14-3.62 ppm (m, $\mathrm{CH}$ and 1 diastereotopic $\mathrm{H}$ of $\mathrm{CH}_{2}$ in PPSO chain), 3.72-3.79 (t, 2H, $\left.\mathrm{HO}-\mathrm{CH}_{2}-\mathrm{CH}_{2}-\mathrm{S}(=\mathrm{O})-\right)$. ATR FT-IR (thin film): $2965\left(v_{\mathrm{s}} \mathrm{CH}_{3}\right), 2916\left(v_{\text {as }} \mathrm{CH}_{2}\right) 2869\left(v_{\text {as }} \mathrm{CH}_{3}\right.$ and $\left.v_{\mathrm{s}} \mathrm{CH}_{2}\right), 1453\left(\delta_{\mathrm{s}} \mathrm{CH}_{2}\right), 1377$ $\left(\delta_{\mathrm{s}} \mathrm{CH}_{3}\right), 1017\left(v_{\mathrm{s}} \mathrm{S}=\mathrm{O}\right), 834,726\left(\rho \mathrm{CH}_{2}\right), 646 \mathrm{~cm}^{-1}(v \mathrm{C}-\mathrm{S})$.

$\mathrm{PPSO}_{2} .{ }^{1} \mathrm{H}$ NMR (d6-DMSO): $\delta=1.35-1.61\left(\mathrm{CH}_{3}\right.$ in $\mathrm{PPSO}_{2}$ chain), $3.09\left(\mathrm{~s}, 3 \mathrm{H},-\mathrm{CH}\left(\mathrm{CH}_{3}\right)-\mathrm{S}\right.$ $(=\mathrm{O})_{2}-\mathrm{CH}_{3}$, terminal methyl) $3.77\left(2 \mathrm{H}, \mathrm{HO}-\mathrm{CH}_{2}-\mathrm{CH}_{2}-\mathrm{S}(=\mathrm{O})_{2}\right.$ - under $\mathrm{H}_{2} \mathrm{O}$ signal), 3.44-3.70 $\left(\mathrm{PPSO}_{2}\right.$ chain: 1 diastereotopic $\left.\mathrm{CH}_{2}\right), 3.77-4.14 \mathrm{ppm}\left(\mathrm{m}, \mathrm{CH}\right.$ and 1 diastereotopic $\mathrm{H}$ of $\mathrm{CH}_{2}$ in PPSO chain). ATR FT-IR (thin film): $2985\left(v_{\mathrm{s}} \mathrm{CH}_{3}\right), 2939\left(v_{\mathrm{as}} \mathrm{CH}_{2}\right) 1663\left(v_{\mathrm{s}} \mathrm{C}=\mathrm{O}\right), 1453\left(\delta_{\mathrm{s}} \mathrm{CH}_{2}\right), 1377\left(\delta_{\mathrm{s}} \mathrm{CH}_{3}\right), 1296$ $\left(v_{\text {as }} \mathrm{S}(=\mathrm{O})_{2}\right) 1121\left(v_{\mathrm{s}} \mathrm{S}(=\mathrm{O})_{2}\right), 844(v \mathrm{~S}-\mathrm{O}), 742 \mathrm{~cm}^{-1}\left(\rho \mathrm{CH}_{2}\right)$.

\subsubsection{FITC-Labelled Polymers}

PEG-amine was synthesized from mPEG-OH using a Mitsunobu reaction as previously described [61]. The synthesis of PPSO-amine is provided in the Supplementary Materials, Section 1SI. In total, $2 \mathrm{~mL}$ of degassed dry DMF (argon bubbling for $45 \mathrm{~min}$ ) were transferred in each position of the reactor with $100 \mathrm{mg}(0.02 \mathrm{mmol})$ of $\mathrm{mPEG}$-amine or PPSO-amine followed first by $8 \mathrm{mg}(0.08$ mmol, 4 equiv.s) of triethylamine (TEA) and then $7.8 \mathrm{mg}(0.02 \mathrm{mmol}, 1$ equiv.s) of FITC in dry DMF (note: Weighing vials were washed after weighting with an additional $100 \mathrm{uL}$ of DMF, which was added into the reaction mixture). The mixture was allowed to react for $24 \mathrm{~h}$ at room temperature. Subsequently, the solution was evaporated using a Genevac EZ2 Elite centrifugal evaporator and the resulting product was dissolved into a small amount of water and dialysed against deionized water for several days, until free dye molecules were completely removed (no fluorescence detected in dialysate).

\subsection{Biochemical/Biological Assays}

\subsubsection{Cell Viability}

The cytotoxicity of mPPSO-OH was assessed on HDFn using mPEG-OH as a control and employing the 3-(4,5-dimethylthiazol-2-yl)-5-(3-carboxymethoxyphenyl)-2-(4-sulfophenyl)-2H-tetrazolium (MTS) assay of mitochondrial reductase activity. HDFs were plated into 96-well plates at a density of 10,000 cells/well, allowing the cells to adhere by incubating them in DMEM complete medium $(10 \%$ FBS) for $24 \mathrm{~h}$. In total, $100 \mu \mathrm{L}$ of $0.01,0.05,0.1,0.5,1,5$, and $10 \mathrm{mg} / \mathrm{mL}$ polymer solutions in the culture medium were introduced into wells containing $100 \mu \mathrm{L}$ of medium. After 24 or $48 \mathrm{~h}$ of incubation at $37^{\circ} \mathrm{C}$, the medium was discarded, cells were gently washed with PBS, and $120 \mu \mathrm{L}$ of MTS solution (Cell Titer 96 Aqueous One Solution Reagent in medium prepared following the manufacturer instructions) 
were added to each well, incubating the plates for $1 \mathrm{~h}$ at $37^{\circ} \mathrm{C}$. Formazan absorbance was measured at $490 \mathrm{~nm}$ and expressed as a percentage of the untreated controls.

\subsubsection{Complement Activation}

The cleavage of complement components $\mathrm{C} 3$ and $\mathrm{C} 5$ was monitored by measuring the formation of their activation products, $\mathrm{C} 3 \mathrm{a}$ and $\mathrm{C} 5 \mathrm{a}$, using a commercial C3a and C5a ELISA kit (Platinum eBioscience kit, Invitrogen, Carlsbad, CA, USA). Activation studies were performed by mixing $450 \mu \mathrm{L}$ of human plasma with $150 \mu \mathrm{L}$ of polymer-PBS solutions (mPPSO-OH, PMOX-OH and mPEG-OH) at concentrations of $0.8,0.4$, or $0.1 \mathrm{mg} / \mathrm{mL}$. The solutions were then incubated in a shaking water bath at $37^{\circ} \mathrm{C}$ for $30 \mathrm{~min}$. Reactions were terminated by addition of the "sample diluent" provided with the assay kit. Control plasma incubations contained phosphate buffered saline (the same volume as the polymer solutions) for assessing background levels of complement activation products. Zymosan (Sigma-Aldrich, St. Louis, MO, USA) was used as a positive control for complement activation. Briefly, the samples were diluted with the dilution buffer provided in the kit and added to a microtiter plate coated with a monoclonal antibody specific for human C3a and C5a. After $1 \mathrm{~h}$ of incubation at room temperature to allow for $\mathrm{C} 3 \mathrm{a}$ and $\mathrm{C} 5 \mathrm{a}$ binding, the plates were washed and incubated for an additional hour with peroxidase-conjugated rabbit anti-C3a, and anti-C5a. Following a final washing step, the chromogenic substrate was added to detect bound C3a, and C5a, recording the absorbance at $450 \mathrm{~nm}$. The values reported are means $+/-$ standard deviations, for $n=3$ and reported as mass of C3a or C5a per $\mathrm{mL}$ of plasma per well.

\subsubsection{Polymer Uptake}

RAW 264.7 macrophages were seeded in black 96-well flat-bottom microtiter plates at a concentration of $2.5 \times 10^{4}$ cells per well and kept at $37{ }^{\circ} \mathrm{C}$, in a $5 \% \mathrm{CO}_{2}$ incubator overnight in DMEM complete medium. Subsequently, the cells were washed once with PBS. Fluorescently labelled PPSO, cationic dextran, and PEG at a concentration of $0.1,0.5,1$, and $2 \mathrm{mg} / \mathrm{mL}$ were added into each well in $100 \mu \mathrm{L}$ of complete medium and incubated for $24 \mathrm{~h}$. For LPS activation, $24 \mathrm{~h}$ after seeding the cells, they were incubated for an additional $24 \mathrm{~h}$ with a $500 \mathrm{ng} / \mathrm{mL}$ LPS solution in DMEM complete medium. Subsequently, $500 \mathrm{ng} / \mathrm{mL}$ of LPS together with fluorescently labelled polymers at concentrations of 0.1 , $0.5,1$, and $2 \mathrm{mg} / \mathrm{mL}$ were added into each well.

Cells were then washed 3 times with PBS and a $0.5 \%$ solution of Triton X-100 in $0.2 \mathrm{~N}$ sodium hydroxide was added for $10 \mathrm{~min}$ at $37{ }^{\circ} \mathrm{C}$ to lyse the cells. The fluorescence of the cell lysates was measured using excitation and emission filters respectively at $485 \pm 20 \mathrm{~nm}$ and $528 \pm 20 \mathrm{~nm}$ and a calibration with dispersions of fluorescently labelled polymers in cell lysates with polymer concentration ranging from 0.05 to $12.5 \mu \mathrm{g} / \mathrm{mL}$.

\subsubsection{ROS-Scavenging Effects of PPSO (Analysis of $\mathrm{H}_{2} \mathrm{O}_{2}$ and $\mathrm{ClO}^{-}$)}

RAW264.7 macrophages were plated in transparent 96-well flat-bottomed plates at a concentration of $2.5 \times 10^{4}$ cells per well and kept at $37^{\circ} \mathrm{C}$, in a $5 \% \mathrm{CO}_{2}$ incubator overnight in DMEM complete medium; the cells were then washed once with PBS and treated for $24 \mathrm{~h}$ with $500 \mathrm{ng} / \mathrm{mL}$ LPS alone or with mPEG-OH or mPPSO-OH at concentrations of $0.1,0.5,1,2$, and $4 \mathrm{mg} / \mathrm{mL}$ in DMEM complete medium. The production of $\mathrm{H}_{2} \mathrm{O}_{2}$ and hypochlorite anion $\left(\mathrm{ClO}^{-}\right)$was assessed on cell lysates (see above) using the Hydrogen Peroxide (colorimetric/fluorometric) and Hypochlorite Assay Kits (colorimetric), respectively. Both kits were used in accordance with the manufacturer's instructions.

\subsubsection{Anti-Inflammatory Effect of PPSO (Analysis of TNF- $\alpha$ )}

RAW264.7 macrophages were seeded in 24-well flat-bottomed plates at a concentration of $1 \times 10^{5}$ cells per well and kept at $37^{\circ} \mathrm{C}$, in a $5 \% \mathrm{CO}_{2}$ incubator overnight. The cells were then washed once with PBS. In total, $500 \mu \mathrm{L}$ of a solution containing $500 \mathrm{ng} / \mathrm{mL}$ LPS alone or with polymers at concentrations of $0.1,0.5,1$, and $2 \mathrm{mg} / \mathrm{mL}$ in DMEM complete medium were added into each well. 
Following a 24-h incubation period, the supernatants were separated and centrifuged at 13,000 rpm for 5 min and were kept at $-80{ }^{\circ} \mathrm{C}$ until the ELISA analysis of TNF- $\alpha$ was performed, using the Cohesion Bioscience Human TNF $\alpha$ ELISA (Enzyme-Linked Immunosorbent Assay) kit. This assay employs 96-well plates coated with an antibody specific for human $\mathrm{TNF} \alpha$, and an HRP-based colorimetric detection (absorbance at $450 \mathrm{~nm}$ ).

\section{Conclusions}

In this study we provided a-proof-of-principle that sulfoxide-based polymers may present both 'stealth' and responsive/pharmacologically active ('drug'-like) features, with clear ROS scavenging activity at least at concentrations above $0.1 \mathrm{mg} / \mathrm{mL}$. Clearly, more detailed investigations on PPSO are required in order to, e.g., ascertain the mechanism of endocytosis, efficiency of ROS removal, interactions with proteins, pharmacokinetics, and in vivo effects on inflammation models, etc. Nevertheless, we believe this paper to be the first report of a 'stealth' polymer that by virtue only of its own main chain - and not of a more or less complex (bio)functionalization-may both be considered on the one hand biocompatible and inert, yet on the other hand, biologically active and anti-inflammatory.

Supplementary Materials: Supplementary materials can be found at http://www.mdpi.com/1422-0067/20/18/ 4583/s1.

Author Contributions: The contributions of the respective authors are as follows: F.E.M. performed all of the biological work. R.d. conceived the original idea, contributed to the experimental work and performed most of the lab supervision. X.Y. contributed to the development of PPSO synthetic methods. Z.Y.T. performed the synthesis of aminated and FITC-labelled PPSO and PEG. A.A. collaborated in the preparation of the grant proposal and co-supervised parts of the project. N.T. was responsible of funding, supervised the overall project, was involved in data analysis and wrote most of the manuscript.

Funding: This research was funded by a) King Saud University (Riyadh, Kingdom of Saudi Arabia), Office of the Vice Rector for Graduate Studies \& Scientific Research, with the collaborative grant "Nanotechnology for drug delivery", through part funding F.E.M.'s salary and consumables; b) the School of Pharmacy of the University of Manchester, through part funding F.E.M.'s PhD studentship, c) the China Scholarship Council (CSC) for X.Y.'s fellowship, d) the Republic of Turkey Ministry of National Education for Zulfiye Yesim Turhan 's PhD studentship.

Conflicts of Interest: The authors declare no conflict of interest. The sponsors had no role in the design, execution, interpretation, or writing of the study.

\section{References}

1. Allen, T.M.; Cullis, P.R. Drug delivery systems: Entering the mainstream. Science 2004, 303, 1818-1822. [CrossRef] [PubMed]

2. Swierczewska, M.; Lee, K.C.; Lee, S. What is the future of PEGylated therapies? Expert Opin. Emerg. Drugs 2015, 20, 531-536. [CrossRef]

3. D'arcy, R.; Tirelli, N. Fishing for fire: Strategies for biological targeting and criteria for material design in anti-inflammatory therapies. Polym. Adv. Technol. 2014, 25, 478-498. [CrossRef]

4. Ekladious, I.; Colson, Y.L.; Grinstaff, M.W. Polymer-drug conjugate therapeutics: Advances, insights and prospects. Nat. Rev. Drug Discov. 2019, 18, 273-294. [CrossRef] [PubMed]

5. Papavasiliou, G.; Sokic, S.; Turturro, M. Synthetic PEG Hydrogels as Extracellular Matrix Mimics for Tissue Engineering Applications. In Biotechnology-Molecular Studies and Novel Applications for Improved Quality of Human Life; InTech: London, UK, 2012.

6. Webster, R.; Elliott, V.; Park, B.K.; Walker, D.; Hankin, M.; Taupin, P. PEG and PEG conjugates toxicity: Towards an understanding of the toxicity of PEG and its relevance to PEGylated biologicals. In Pegylated Protein Drugs: Basic Science and Clinical Applications; Springer: Basel, Switzerland, 2009.

7. Hatakeyama, H.; Akita, H.; Harashima, H. The Polyethyleneglycol Dilemma: Advantage and Disadvantage of PEGylation of Liposomes for Systemic Genes and Nucleic Acids Delivery to Tumors. Biol. Pharm. Bull. 2013, 36, 892-899. [CrossRef] [PubMed]

8. Abuchowski, A.; Vanes, T.; Palczuk, N.C.; Davis, F.F. Alteration of Immunological Properties of Bovine Serum-Albumin by Covalent Attachment of Polyethylene-Glycol. J. Biol. Chem. 1977, 252, 3578-3581. [PubMed] 
9. Duncan, R. Development of HPMA copolymer-anticancer conjugates: Clinical experience and lessons learnt. Adv. Drug Deliv. Rev. 2009, 61, 1131-1148. [CrossRef]

10. Duncan, R.; Vicent, M.J. Do HPMA copolymer conjugates have a future as clinically useful nanomedicines? A critical overview of current status and future opportunities. Adv. Drug Deliv. Rev. 2010, 62, 272-282. [CrossRef]

11. Francini, N.; Cochrane, D.; Illingworth, S.; Purdie, L.; Mantovani, G.; Fisher, K.; Seymour, L.W.; Spain, S.G.; Alexander, C. Polyvalent Diazonium Polymers Provide Efficient Protection of Oncolytic Adenovirus Enadenotucirev from Neutralizing Antibodies while Maintaining Biological Activity In Vitro and In Vivo. Bioconjug. Chem. 2019, 30, 1244-1257. [CrossRef]

12. Immordino, M.L.; Dosio, F.; Cattel, L. Stealth liposomes: Review of the basic science, rationale, and clinical applications, existing and potential. Int. J. Nanomed. 2006, 1, 297-315.

13. Zelikin, A.N.; Such, G.K.; Postma, A.; Caruso, F. Poly(vinylpyrrolidone) for bioconjugation and surface ligand immobilization. Biomacromolecules 2007, 8, 2950-2953. [CrossRef] [PubMed]

14. Gaertner, F.C.; Luxenhofer, R.; Blechert, B.; Jordan, R.; Essler, M. Synthesis, biodistribution and excretion of radiolabeled poly(2-alkyl-2-oxazoline)s. J. Control. Release 2007, 119, 291-300. [CrossRef] [PubMed]

15. Zalipsky, S.; Hansen, C.B.; Oaks, J.M.; Allen, T.M. Evaluation of blood clearance rates and biodistribution of poly(2-oxazoline)-grafted liposomes. J. Pharm. Sci. 1996, 85, 133-137. [CrossRef]

16. Torchilin, V.P.; Trubetskoy, V.S.; Whiteman, K.R.; Caliceti, P.; Ferruti, P.; Veronese, F.M. New Synthetic Amphiphilic Polymers for Steric Protection of Liposomes in-Vivo. J. Pharm. Sci. 1995, 84, 1049-1053. [CrossRef] [PubMed]

17. Drotleff, S.; Lungwitz, U.; Breunig, M.; Dennis, A.; Blunk, T.; Tessmar, J.; Gopferich, A. Biomimetic polymers in pharmaceutical and biomedical sciences. Eur. J. Pharm. Biopharm. 2004, 58, 385-407. [CrossRef] [PubMed]

18. Kohori, F.; Sakai, K.; Aoyagi, T.; Yokoyama, M.; Yamato, M.; Sakurai, Y.; Okano, T. Control of adriamycin cytotoxic activity using thermally responsive polymeric micelles composed of poly(N-isopropylacrylamide-co-N,N-dimethylacrylamide)-b-poly(D,L-lactide). Colloid Surf. B 1999, 16, 195-205. [CrossRef]

19. Lila, A.S.A.; Kiwada, H.; Ishida, T. The accelerated blood clearance (ABC) phenomenon: Clinical challenge and approaches to manage. J. Control. Release 2013, 172, 38-47. [CrossRef]

20. Ishida, T.; Kiwada, H. Accelerated blood clearance (ABC) phenomenon upon repeated injection of PEGylated liposomes. Int. J. Pharm. 2008, 354, 56-62. [CrossRef]

21. Dams, E.T.M.; Laverman, P.; Oyen, W.J.G.; Storm, G.; Scherphof, G.L.; Van der Meer, J.W.M.; Corstens, F.H.M.; Boerman, O.C. Accelerated blood clearance and altered biodistribution of repeated injections of sterically stabilized liposomes. J. Pharm. Exp. Ther. 2000, 292, 1071-1079.

22. Ishida, T.; Ichihara, M.; Wang, X.; Yamamoto, K.; Kimura, J.; Majima, E.; Kiwada, H. Injection of PEGylated liposomes in rats elicits PEG-specific IgM, which is responsible for rapid elimination of a second dose of PEGylated liposomes. J. Control. Release 2006, 112, 15-25. [CrossRef]

23. Wang, X.Y.; Ishida, T.; Kiwada, H. Anti-PEG IgM elicited by injection of liposomes is involved in the enhanced blood clearance of a subsequent dose of PEGylated liposomes. J. Control. Release 2007, 119, 236-244. [CrossRef] [PubMed]

24. Hamada, I.; Hunter, A.C.; Szebeni, J.; Moghimi, S.M. Poly(ethylene glycol)s generate complement activation products in human serum through increased alternative pathway turnover and a MASP-2-dependent process. Mol. Immunol. 2008, 46, 225-232. [CrossRef] [PubMed]

25. Moghimi, S.M.; Hunter, A.C.; Dadswell, C.M.; Savay, S.; Alving, C.R.; Szebeni, J. Causative factors behind poloxamer 188 (pluronic F68, Flocor (TM))-induced complement activation in human sera. A protective role against poloxamer-mediated complement activation by elevated serum lipoprotein levels. BBA Mol. Basis Dis. 2004, 1689, 103-113. [CrossRef]

26. Ishida, T.; Kashima, S.; Kiwada, H. The contribution of phagocytic activity of liver macrophages to the accelerated blood clearance (ABC) phenomenon of PEGylated liposomes in rats. J. Control. Release 2008, 126, 162-165. [CrossRef] [PubMed]

27. Matsumura, Y.; Maeda, H. A New Concept for Macromolecular Therapeutics in Cancer-ChemotherapyMechanism of Tumoritropic Accumulation of Proteins and the Antitumor Agent Smancs. Cancer Res. 1986, 46, 6387-6392. [PubMed] 
28. Kierstead, P.H.; Okochi, H.; Venditto, V.J.; Chuong, T.C.; Kivimae, S.; Frechet, J.M.J.; Szoka, F.C. The effect of polymer backbone chemistry on the induction of the accelerated blood clearance in polymer modified liposomes. J. Control. Release 2015, 213, 1-9. [CrossRef] [PubMed]

29. Li, S.P.; Chung, H.S.; Simakova, A.; Wang, Z.Y.; Park, S.; Fu, L.Y.; Cohen-Karni, D.; Averick, S.; Matyjaszewski, K. Biocompatible Polymeric Analogues of DMSO Prepared by Atom Transfer Radical Polymerization. Biomacromolecules 2017, 18, 475-482. [CrossRef]

30. Carampin, P.; Lallana, E.; Laliturai, J.; Carroccio, S.C.; Puglisi, C.; Tirelli, N. Oxidant-Dependent REDOX Responsiveness of Polysulfides. Macromol. Chem. Phys. 2012, 213, 2052-2061. [CrossRef]

31. Pitha, J.; Szente, L.; Greenberg, J. Poly-L-Methionine Sulfoxide-a Biologically Inert Analog of Dimethylsulfoxide with Solubilizing Potency. J. Pharm. Sci. 1983, 72, 665-668. [CrossRef]

32. Hofman, V.; Ringsdorf, H.; Muacevic, G. Pharmakologisch aktive Polymere, 8*. Poly[2-(rnethylsulfinyl) athylacrylat]e und ihre verrnittelnde Wirkung auf die transkutane Resorption von Pharrnaka. Makromol. Chem. 1975, 176, 1929-1943. [CrossRef]

33. Sun, Y.; Lathwal, S.; Wang, Y.; Fu, L.Y.; Olszewski, M.; Fantin, M.; Enciso, A.E.; Szczepaniak, G.; Das, S.; Matyjaszewski, K. Preparation of Well-Defined Polymers and DNA-Polymer Bioconjugates via Small-Volume eATRP in the Presence of Air. ACS Macro Lett. 2019, 8, 603-609. [CrossRef]

34. Navarro, L.A.; Enciso, A.E.; Matyjaszewski, K.; Zauscher, S. Enzymatically Degassed Surface-Initiated Atom Transfer Radical Polymerization with Real-Time Monitoring. J. Am. Chem. Soc. 2019, 141, 3100-3109. [CrossRef] [PubMed]

35. Fu, C.K.; Zhang, C.; Peng, H.; Han, F.; Baker, C.; Wu, Y.; Ta, H.; Whittaker, A.K. Enhanced Performance of Polymeric F-19 MRI Contrast Agents through Incorporation of Highly Water-Soluble Monomer MSEA. Macromolecules 2018, 51, 5875-5882. [CrossRef]

36. Li, S.P.; Omi, M.; Cartieri, F.; Konkolewicz, D.; Mao, G.; Gao, H.F.; Averick, S.E.; Mishina, Y.; Matyjaszewski, K. Cationic Hyperbranched Polymers with Biocompatible Shells for siRNA Delivery. Biomacromolecules 2018, 19, 3754-3765. [CrossRef] [PubMed]

37. McKim, A.S.; Strub, R. Advances in the Regulated Pharmaceutical Use of Dimethyl Sulfoxide USP, Ph.Eur. Pharm. Technol. 2016, 28, s30-s35.

38. Yi, X.Y.; Liu, M.X.; Luo, Q.; Zhuo, H.L.; Cao, H.; Wang, J.X.; Han, Y. Toxic effects of dimethyl sulfoxide on red blood cells, platelets, and vascular endothelial cells in vitro. FEBS Open Bio 2017, 7, 485-494. [CrossRef] [PubMed]

39. Costa, L.D.; Ottoni, M.H.F.; dos Santos, M.G.; Meireles, A.B.; de Almeida, V.G.; Pereira, W.D.; de Avelar-Freitas, B.A.; Brito-Melo, G.E.A. Dimethyl Sulfoxide (DMSO) Decreases Cell Proliferation and TNF-alpha, IFN-gamma, and IL-2 Cytokines Production in Cultures of Peripheral Blood Lymphocytes. Molecules 2017, 22, 1789. [CrossRef]

40. Elisia, I.; Nakamura, H.; Lam, V.; Hofs, E.; Cederberg, R.; Cait, J.; Hughes, M.R.; Lee, L.; Jia, W.; Adomat, H.H.; et al. DMSO Represses Inflammatory Cytokine Production from Human Blood Cells and Reduces Autoimmune Arthritis. PLoS ONE 2016, 11, e0152538. [CrossRef]

41. Chen, Q.; Olashaw, N.; Wu, J. Participation of reactive oxygen species in the lysophosphatidic acid-stimulated mitogen-activated protein kinase kinase activation pathway. J. Biol. Chem. 1995, 270, 28499-58502. [CrossRef]

42. El-Mohtadi, F.; d'arcy, R.; Tirelli, N. Oxidation-Responsive Materials: Biological Rationale, State of the Art, Multiple Responsiveness, and Open Issues. Macromol. Rapid Commun. 2019, 40, 1800699. [CrossRef]

43. Khutoryanskiy, V.V.; Tirelli, N. Oxidation-responsiveness of nanomaterials for targeting inflammatory reactions. Pure Appl. Chem. 2008, 80, 1703-1718. [CrossRef]

44. Rajkovic, O.; Gourmel, C.; d'Arcy, R.; Wong, R.; Rajkovic, I.; Tirelli, N.; Pinteaux, E. Reactive Oxygen Species-Responsive Nanoparticles for the Treatment of Ischemic Stroke. Adv. Ther. 2019, 2, 1900038. [CrossRef]

45. Jeanmaire, D.; Laliturai, J.; Almalik, A.; Carampin, P.; d’Arcy, R.; Lallana, E.; Evans, R.; Winpenny, R.E.P.; Tirelli, N. Chemical specificity in REDOX-responsive materials: The diverse effects of different Reactive Oxygen Species (ROS) on polysulfide nanoparticles. Polym. Chem. 2014, 5, 1393-1404. [CrossRef]

46. Wang, L.; Kilcher, G.; Tirelli, N. Avoiding Disulfides: Improvement of Initiation and End-Capping Reactions in the Synthesis of Polysulfide Block Copolymers. Macromol. Chem. Phys. 2009, 210, 447-456. [CrossRef]

47. D'arcy, R.; Siani, A.; Lallana, E.; Tirelli, N. Influence of Primary Structure on Responsiveness. Oxidative, Thermal, and Thermo-Oxidative Responses in Polysulfides. Macromolecules 2015, 48, 8108-8120. 
48. Page, P.C.B.; Buckley, B.R.; Elliott, C.; Chan, Y.; Dreyfus, N.; Marken, F. Chemoselective Oxidation of Sulfides to Sulfoxides with Urea-Hydrogen Peroxide Complex Catalysed by Diselenide. Synlett 2016, 27, 80-82. [CrossRef]

49. Fanucchi, M.; Glaspy, J.; Crawford, J.; Garst, J.; Figlin, R.; Sheridan, W.; Menchaca, D.; Tomita, D.; Ozer, H.; Harker, L. Effects of polyethylene glycol-conjugated recombinant human megakaryocyte growth and development factor on platelet counts after chemotherapy for lung cancer. N. Engl. J. Med. 1997, 336, 404-409. [CrossRef]

50. Wang, Q.; Jiang, J.Y.; Chen, W.F.; Jiang, H.; Zhang, Z.R.; Sun, X. Targeted delivery of low-dose dexamethasone using PCL-PEG micelles for effective treatment of rheumatoid arthritis. J. Control Release 2016, 230, 64-72. [CrossRef]

51. Poljsak, B.; Suput, D.; Milisav, I. Achieving the Balance between ROS and Antioxidants: When to Use the Synthetic Antioxidants. Oxid. Med. Cell. Longev. 2013, 956792. [CrossRef]

52. Woffindin, C.; Hoenich, N.A.; Matthews, J.N.S. Cellulose-biased hemodialysis membranes-Biocompatibility and functional performance compared. Nephrol. Dial. Transplant. 1992, 7, 340-345. [CrossRef]

53. Payne, M.S.; Horbett, T.A. Complement Activation by Hydroxyethylmethacrylate-Ethylmethacrylate Copolymers. J. Biomed. Mater. Res. 1987, 21, 843-859. [CrossRef] [PubMed]

54. Lamba, N.M.K.; Courtney, J.M.; Gaylor, J.D.S.; Lowe, G.D.O. In vitro investigation of the blood response to medical grade PVC and the effect of heparin on the blood response. Biomaterials 2000, 21, 89-96. [CrossRef]

55. Passirani, C.; Barratt, G.; Devissaguet, J.P.; Labarre, D. Interactions of nanoparticles bearing heparin or dextran covalently bound to poly(methyl methacrylate) with the complement system. Life Sci. 1998, 62, 775-785. [CrossRef]

56. Gaucher, G.; Asahina, K.; Wang, J.H.; Leroux, J.C. Effect of Poly(N-vinyl-pyrrolidone)-block-poly(D,L-lactide) as Coating Agent on the Opsonization, Phagocytosis, and Pharmacokinetics of Biodegradable Nanoparticles. Biomacromolecules 2009, 10, 408-416. [CrossRef] [PubMed]

57. Tauhardt, L.; Pretzel, D.; Kempe, K.; Gottschaldt, M.; Pohlers, D.; Schubert, U.S. Zwitterionic poly(2-oxazoline)s as promising candidates for blood contacting applications. Polym. Chem. 2014, 5, 5751-5764. [CrossRef]

58. Mosqueira, V.C.F.; Legrand, P.; Gulik, A.; Bourdon, O.; Gref, R.; Labarre, D.; Barratt, G. Relationship between complement activation, cellular uptake and surface physicochemical aspects of novel PEG-modified nanocapsules. Biomaterials 2001, 22, 2967-2979. [CrossRef]

59. Yu, J.; Lamba, N.M.K.; Courtney, J.M.; Whateley, T.L.; Gaylor, J.D.S.; Lowe, G.D.O.; Ishihara, K.; Nakabayashi, N. Polymeric Biomaterials-Influence of Phosphorylcholine Polar Groups on Protein Adsorption and Complement Activation. Int. J. Artif. Organs 1994, 17, 499-504. [CrossRef] [PubMed]

60. Xiao, H.D.; Xin, K.; Dou, H.F.; Yin, G.; Quan, Y.W.; Wang, R.Y. A fast-responsive mitochondria-targeted fluorescent probe detecting endogenous hypochlorite in living RAW 264.7 cells and nude mouse. Chem. Commun. 2015, 51, 1442-1445. [CrossRef]

61. D'arcy, R.; Tirelli, N. Mitsunobu Reaction: A Versatile Tool for PEG End Functionalization. Macromol. Rapid Commun. 2015, 36, 1829-1835. [CrossRef]

(C) 2019 by the authors. Licensee MDPI, Basel, Switzerland. This article is an open access article distributed under the terms and conditions of the Creative Commons Attribution (CC BY) license (http://creativecommons.org/licenses/by/4.0/). 